\title{
ANALISIS PENGELOLAAN KONDISI FISIK RUANG TERBUKA HIJAU PUBLIK (RTHP) DI KECAMATAN UMBULHARJO
}

\author{
Muhammad Riski Hariyanto ${ }^{1}$, Ahmad Faizal Rangkuti ${ }^{2}$ \\ ${ }^{1}$ 'Fakultas Kesehatan Masyarakat, Universitas Ahmad Dahlan \\ Email: faizal.rangkuti@ikm.uad.ac.id
}

\begin{abstract}
ABSTRAK
Ruang terbuka hijau public (RTHP) merupakan kawasan lahan hijau yang dapat dimanfaatkan sebagai tempat untuk bersosialisasi, rekreasi, dan ekonomi. Kota Yogyakarta sebagai kota metropolitan dengan intensitas ruang terbangun yang sangat padat hanya memiliki sedikit RTHP, sebagai contoh RTHP Tahunan, Semaki, dan Gajahwong. Tujuan penelitian ini adalah mengetahui pengelolaan kondisi fisik, mengetahui pengelolaan, mengetahui vegetasi, mengetahui fasilitas, mengidentifikasi kondisi fisik, mengetahui aksesibilitas, dan mengetahui partisipasi masyarakat yang mana semuanya berada di RTHP Kecamatan Umbulharjo. Jenis penelitian ini menggunakan dekstriptif kualitatis. Pengambilan data wawancara mendalam. Keabsahan data menggunakan teknik triangulasi. Instrumen penelitian yaitu peneliti, pedoman wawancara, alat tulis, dan rekam. Analisis menggunakan analysis interactive. Pengelolaan RTHP Gajahwong melakukan perawatan setiap hari memiliki petugas 3 personil sedangkan RTHP Tahunan dan Semaki melakukan perawatan 2 hari sekali memiliki petuas 2 personil. Vegetasi ketiga RTHP sudah baik. Fasilitas di RTHP Gajahwong dan Semaki bervariasi dan lengkap seperti adanya area bermain, bangku, sampai tersedianya toilet dan tempat sampah sedangkan RTHP Tahunan sebaliknya. Kondisi fisik terhadap kebersihan di RTHP Gajahwong dan Semaki baik sedangkan RTHP Tahunan sebaliknya, RTHP Gajawong dan Tahunan memiliki akses eksternal yang baik dapat dilewati mobil dan motor sedangkan RTHP Semaki sebaliknya. Partisipasi masyarakat di RTHP Gajahwong dan Semaki baik menjaga dan merawat sedangkan RTHP Tahunan kurang baik.

RTHP Gajahwong memiliki perawatan yang lebih rutin daripada RTHP Tahunan dan Semaki. Ketiga RTHP memiliki kondisi vegetasi yang sama. RTHP Gajahwong dan Semaki memliki fasilitas yang lengkap sedangkan RTHP Tahunan sebaliknya. RTHP Gajahwong dan Semaki memiliki fasilitas yang lengkap sedangkan Tahunan sebaliknya. RTHP Gajahwong dan Semaki memiliki kondisi fisik kebersihan yang baik sedangkan Tahunan sebaliknya. Menuju RTHP Gajahwong dan Tahunan bisa dilewati mobil dan motor sedangkan Semaki sebaliknya. Partisipasi masyarakat di RTHP Gajahwong dan Semaki baik sedangkan Tahunan sebaliknya.
\end{abstract}

Kata Kunci: RTHP Gajahwong, RTHP Semaki, RTHP Tahunan 


\begin{abstract}
Public green open space (RTHP) is an area of green land that can be used as a place for socializing, recreation, and economy. Yogyakarta City as a metropolitan city with a very dense built space intensity has only a little RTHP, for example Annual RTHP, Semaki, and Gajahwong. The purpose of this study is to know the management of physical conditions, know management, know vegetation, know facilities, identify physical conditions, find out accessibility, and know community participation which are all in RTHP Umbulharjo District. This type of research uses descriptive qualitative. Retrieval of in-depth interview data. The validity of the data uses triangulation techniques. Research instruments are researchers, interview guidelines, stationery, and records. Analysis using interactive analysis. Result: Management of RTHP Gajahwong carries out maintenance every day and had 3 personnel while Annual RTHP and Semaki did maintenance every 2 days and has 2 personnel. The third vegetation of RTHP was good. Facilities in Gajahwong and Semaki RTHP were varied and complete such as played areas, benches, to the availability of toilets and garbage bins while Annual RTHP were the opposite. The physical condition of cleanliness in Gajahwong and Semaki RTHP were good while the Annual RTHP on the contrary, Gajawong and Annual RTHP had good external access by cars and motorbikes while Semaki RTHP were the opposite. Community participation in the RTHP Gajahwong and Semaki were good at looking after and caring while the Annual RTHP were not good. RTHP Gajahwong had more routine maintenance than Annual RTHP and Semaki. All three RTHP had the same vegetation conditions. RTHP Gajahwong and Semaki had complete facilities while the Annual RTHP were the opposite. RTHP Gajahwong and Semaki have complete facilities while the Annual vice versa. RTHP Gajahwong and Semaki had good physical hygiene conditions while Annual vice versa. Towards Gajahwong and Annual RTHP cars and motorbikes could be passed while Semaki is the opposite. Community participation in Gajahwong and Semaki RTHP were good while Annual were the opposite.
\end{abstract}

Keywords: RTHP Gajahwong, RTHP Semaki,RTHP Tahunan 


\section{LATAR BELAKANG}

Ruang terbuka hijau publik (RTHP) merupakan kawasan lahan hijau yang dapat dimanfaatakan sebagai tempat untuk bersosialisasi, rekreasi dan ekonomi. Pembangunan yang ada di kota-kota besar di Indonesia umumnya tidak memperhatikan unsur ruang terbuka hijau. Kesulitan dalam hal pemenuhan proporsi ruang terbuka hijau yang kini dirasakan di kota-kota besar mulai tertular ke kota-kota kecil. Namun, pengelola perkotaan dan masyarakat yang tidak menghargai nilai RTHP juga masih terlihat banyak kota kecil yang semakin gersang karena pepohonannya ditebang untuk pelebaran jalan atau kegiatan perkotaan lainnya. Perkembangan kota akhirakhir ini sering kali hanya berorientasi pada peningkatan aspek ekonomi tanpa mempertimbangkan unsur ekologi(Siregar, M, A, 2014).

Perkembangan kota yang terjadi cukup pesat salah satunya disebabkan oleh semakin bertambahnya jumlah penduduk. Peningkatan jumlah penduduk di perkotaan disebabkan oleh pertambahan alami dan adanya perpindahan penduduk dari desa ke kota. Urbanisasi dapat menimbulkan berbagai macam masalah yang dapat terjadi jika tidak ada pengendaliannya. Masalah urbanisasi yang dihadapi oleh Indonesia saat ini adalah pertumbuhan penduduk yang terkonsentrasi di kota, sehingga muncul masalah salah satunya yaitu meningkatnya angka kemiskinan yang menyebabkan terjadinya peningkatan pemukiman kumuh, peningkatan urban crime dan masih banyak masalah lain(Harahap, 2013).

Sebagai pusat perkembangan, kawasan perkotaan akan menarik dan meningkatkan rasio kependudukan di suatu wilayah. Pertumbuhan penduduk yang meningkat akan berdampak kembali kepada peningkatan pembangunan untuk permukiman di kawasan perkotaan. Perkembangan pembangunan kota saat ini menunjukkan kecenderungan terjadinya aktivitas pembangunan yang tidak seimbang yang mengakibatkan kondisi lingkungan terganggu(Rushayati, S et al., 2011).

RTHP kota adalah bagian dari ruang terbuka suatu wilayah perkotaan yang diisi oleh tumbuhan, tanaman, dan vegetasi guna mendukung manfaat langsung atau tidak langsung yang dapat digunakan bagi masyarakat hasil dari RTHP dalam kota tersebut yaitu keamanan, kenyamanan, kesejahteraan, dan keindahan untuk masyarakat yang ada di wilayah perkotaan tersebut(Kementerian Pekerjaan Umum, 2008).

Peraturan yang membahas tentang RTHP salah satunya dari Undang-Undang No. 26/ 2007 tentang Penataan Ruang dimana disyaratkan luas RTH minimum sebesar 30\% dari luas wilayah kawasan perkotaan yang dibagi menjadi RTH Publik minimal 20\% dan RTH Privat minimal $10 \%$. Pada kenyataannya di Indonesia, terjadi penurunan kuantitas Ruang Terbuka Hijau yang sangat signifikan di kawasan perkotaan yang menyebabkan menurunan kualitas ruang terbuka publik perkotaan. Semakin sempitnya RTH, khususnya taman dapat menimbulkan munculnya kerawanan dan penyakit sosial sifat individualistik dan ketidakpedulian terhadap lingkungan yang sering ditemukan di masyarakat perkotaan. Disamping ini semakin terbatasnya RTH juga berpengaruh terhadap peningkatan iklim mikro, pencemaran udara, banjir dan berbagai dampak negatif lingkungan lainnya(Nugroho, 2015).

Kota Yogyakarta merupakan salah satu tempat destinasi wisata yang diminati banyak pendatang dari luar kota yogyakarta ingin berkunjung menikmati wisata alam maupun wisata sejarah. Sehingga mangakibatkan terjadinya penumpukan kepadatan penduduk dan tidak sebanding dengan pertu mbuhan ruang terbuka hijau karena mulai sempitnya lahan kosong salah satu imbas dari kepadatan penduduk banyak terdapat kawasan pemukiman kumuh seperti bantaran sungai dan rel kereta api. Kota Yogyakarta sebagai kota metropolitan dengan intensitas ruang terbangun yang sangat padat hanya memiliki sedikit RTHP. RTHP yang ada di Kota Yogyakarta baru dapat terpenuhi seluas 17,7\%\% dari luas wilayah. Pemerintah mengalami berbagai kendala baik itu dari sisi penyediaan secara fisik maupun pada saat pen gelolaan RTHP(Budiman, Sulistyantara and Zain, 2014). 
Data Dinas Lingkungan Hidup kota Yogyakarta mulai tahun 2013 sd 2018 DLH memiliki luas total RTHP $23.585 \mathrm{~m}^{2}$ yang mereka kelola, ruang lingkup lokasi RTHP yang menjadi tanggung jawab DLH Yogyakarta meliputi 13 kecamatan dan 40 kelurahan yang semuanya dikelola oleh DLH kota Yogyakarta. Kecamatannya meliputi Ngampilan, Gedongtengen, Kraton, Kotagede, Mergangsan, Pakualaman, Gondokusuman, Mantrijeron, Jetis, Gondokusuman, Umbulharjo, Tegalrejo, Dangurejan. Dari 13 kecamatan tersebut terdapat satu kecamatan yang memiliki RTHP terbanyak yaitu kecamatan Umbulharjo dengan total RHTP 12 titik, di kota Yogyakarta RTHP yang paling luas yaitu RTHP Gajahwong Edupark dengan total luas mencapai $5000 \mathrm{~m}^{2}$. Pembangunan RTHP dikota Yogyakarta mulai tahun 2013 sd 2018 selalu mengalami peningkatan pembangunan RTHP puncak pembangunan yang terbesar yaitu pada tahun 2015 dengan total 6715 m²(DLH Kota Yogyakarta, 2018).

Berdasarkan studi pendahuluan dari ketiga titik lokasi yaitu RTHP Semaki, RTHP Tahunan, dan RTHP Pandeyan yang akan diteliti memiliki kondisi fisik yang berbeda-beda. Sehingga perlu dilakukan pengkajian bagaimana kondisnya agar dapat menjadi masukan untuk pemerintah dan masyarakat dalam menjaga keberlangsungan RTHPnya.

\section{METODE PENELITIAN}

Jenis penelitian yang digunakan yaitu jenis penelitian dengan metode deskriptif kualitatif. Cara pengambilan data dengan menggunakan wawancara mendalam. Analisis data menggunakan analisys interaktif dan keabsahan data menggunakan teknik triangulasi.

\section{HASIL DAN PEMBAHASAN}

\section{Pengelolaan RTHP}

RTHP merupakan tempat ruang terbuka yang berfungsi sebagai sarana interaksi sosial, sarana ekstetika kota, pengendalian tata air, keanakaragaman hayati dan pengendalian pencermaran. DLH merupakan dinas yang bertugas penuh pengelolan dan perawat di RTHP kota(Perwali, 2016). Perawatan RTHP Gajahwong Edupark yang memiliki luas mencapai $5000 \mathrm{~m} 2$ dilakukan oleh pihak DLH setiap hari. Perawatan di RTHP Gajahwong meliputi penyiraman, bersih-bersih seperti menyapu, merapikan tanaman, menyabut rumput, dan penyiraman, pemangkasan, pembibitan, dan pemupukan. Jumlah anggota yang melakukan perawatan mencapai 3 personil. RTHP Gajahwong Edupark merupakan salah satu RTHP edukasi yang ada dikota Yogyakarta sehingga harus memiliki perawatan yang lebih ekstra. Waktu kegiatan perawatan yang dilakukan oleh pihak DLH pagi hari namun lama waktu perawatan fleksibel tergantung kondisi dilapangan. Informasi tersebut berdasarkan hasil wawancara sebagai berikut.

Lebih banyak bersih-bersih dan nyiram tanaman namun untuk pemotongan yang bersekala besar biasanya pihak DLH . kadang- 6 kadang kan kita harus ngasih masukan ke pihak DLH ini loh saatnya dipotong jadi kita yang kordinasi, kemarin kan kita agak lambat untuk kondinasi sehingga pohon terlalu rimbun matahari sulit masuk kecelah-celah area RTHP itu yang menimbulkan kelebaban area tersebut sehingga banyak nyamuk yang bisa saja mengganggu kenyamanan masyarakat. Unutuk penyemprotan hama biasanya jarang mas gak nentu, sekarang rata-rata pihak DLH mengirimkan 3 (tiga) personil” (Informan 3).

RTHP Tahunan dan RTHP Semaki yang sama-sama memiliki kesamaan frekuensi perawatan oleh pihak DLH yaitu 2 kali dalam seminggu dengan jumlah anggota yang melakukan perawatan 2 personil, waktu perawatan yang dilakukan pihak DLH pada pagi hari. Kegiatan yang dilakukan ke 3 RTHP tersebut meliputi pembersihan menyapu dan penyiraman merupakan kegiatan pokok yang harus dilakukan setiap minggunya sedangkan 
pemangkasan dan pemupukan hanya dilakukan sebulan sekali, namun untuk pengendalian hama pihak DLH fleksibel melakukannya berdasarkan kondisi yang disana dan keparahan. Informasi tersebut berdasarkan hasil wawancara sebagai berikut.

"Eemm kurang tau persis ya mas biasanya sih sering seminggu 1 kali sampai 2 kali penyiraman . waktu yang sering dilakukan biasanya dilakukan pagi hari dengan jumlah 2 orang. Kegiatan yang dilakukan pihak DLH biasanya bersih-bersih taman seperti nyiram, motong tanaman, dan penghijauan tapi kalo untuk pemupukan dan hama saya kurang tau mas heheh" (Informan 2).

Hal tersebut sudah sejalan dengan peraturan PERMEN PU No 5 tahun 2012 bahwa kegiatan perawatan meliputi penyiraman setiap hari, pemangkasan agar tidak menggangu dan mempertahankan bentuk tanaman, pemupukan dilakukan sebulan sekali dan penghamaan dilakukan seminggu sekali (Kementerian Pekerjaan Umum, 2012).

\section{Vegetasi}

Vegetasi merupakan komponen terpenting RTHP yang berfungsi sebagai pengendalian pencermaran, meningkatkan kadar oksigen dan sebagai peneduh. Penilaian vegetasi meliputi terdapat tanaman berkayu keras, tidak berkayu, tumbuh alami dan sengaja ditanam, selain itu melihat dari perawatan meliputi penyiraman, pemangkasan, pemupukan dan pengendalian hama (Kementerian Pekerjaan Umum, 2008).

Vegetasi yang ada di ketiga RTHP tersebut didapatkan bahwa vegetasi disana beranekaragam seperti tanaman berkayu serta tanaman tidak berkayu. Seluruh tanaman disana sengaja ditanam dan tidak ada tanaman liar. Kondisi vegetasi di RTHP Gajahwong yaitu jumlah tumbuhan yang berukuran besar dan rimbun sudah banyak tetapi tumbuhan hiasan berukuran kecil yang berfungsi untuk mempercantik RTHP masih kurang. Kondisi Vegetasi di RTHP Tahunan yaitu jumlah tanaman di RTHP Tahunan belum cukup karena kurangnya pohon besar disana dan ada beberapa tanaman sudah kering. Kondisi vegetasi di RTHP Semaki yaitu bahwa pohon besar dan tumbuhan kecil sudah cukup banyak ditambah ditumbuhkan dan dikembangkannya tanaman TOGA. Informasi tersebut berdasarkan hasil wawancara sebagai berikut.

"Saya kira dari segi jumalah tanaman yang berukuran besar sudah cukup namun tanaman yang berukuran kecil saya kira masih kurang mas, alhamdulillah setiap hari ada yang membersihkan disini mas" (Informan 2).

"Saya kira kurang mas masih kurang ngiup kalo siang hari mau neduh ditaman itu susah mas, ada sih pohon besar untuk teduh tapi kelihatanya masih kurang rimbun gersang banget mas, makanya taman disini rame biasanya sore sampe malam, ada sih petugas yang pake baju hijau sering bersih-bersih disini lah nyiram, nyapu dan lain-lain. Barusan bulan ini ada pengijauan di taman ini mas oleh dinas" (Informan 3).

"Sudah enak mas pohonnya sudah cukup, kalo mau ditambah lagi lahannya dimana mas sudah padat banget apa lagi disinikan kawasan padat penduduk, agak sulit buat cari lahan. Program yang lagi kami lakukan tanaman TOGA mas passs banget dibelakang balai dusun ada lahan sedikit yang nanti kami mau usulkan ke dinas pertamanan agar dibuatkan tanaman TOGA.kesadaran masyarakat disini bagus mas mereka setiap sore menyupu, nyiram tanaman dan ngepel balai dusun. Eeeeeemmmm kalo dari dlh biasanya sama mas tapi ada pemberian pupuk dan pemangkasan biasanya loh ya sebulan sekali mas" (Informan 3).

Berdasarkan temuan di lapangan bahwa kegiatan yang dilakukan pihak DLH dalam merawat vegetasi seperti penyiraman dan menyapu kegiatan pokok namun untuk pengomposan dan pemupukan dilakukan sebulan sekali. Pengendalian hama dilakukan fleksibel tergantung kondisinya. 


\section{Penilaian Fasilitas}

Fasilitas utama yang ada di RTHP ketiga tersebut yang paling lengkap yaitu RTHP Gajahwong Edupark meliputi area bermain dengan jumlah yang cukup banyak, area terbuka, trek lari, disetiap sudut RTHP tersedia bangku, dan ditengah RTHP terdapat panggung. Fasilitas area bermain meliputi alat permainan anak seperti ayunan, playgroud, jungkatjungkit dan prosotan yang berada di sebelah timur dan selatan RTHP. Trek lari yang mengelilingi RTHP tersebut cukup panjang dengan lebar 2 meter disisi kanan dan kiri ditanami berbagai macam tumbuhan bunga. Area terbuka yang ada di RTHP Gajahwong Edupark meliputi lapangan yang dimana digunakan sebagai tempat berolahraga dan terdapat area penghijauan disetiap sudut RTHP tersebut yang berguna untuk penyediaan oksigen. Bangku yang tersedia di RTHP Gajahwong Edupark dilengkapi dengan peneduh (gazebo) berguna untuk melindungi masyarakat dari terik matahari dan hujan. Fasilitas panggung yang ada di RTHP tersebut berguna untuk kegiatan acara sosial maupun kesenian bagi masyarakat. Informasi tersebut berdasarkan hasil wawancara sebagai berikut.

"Fasilitas disini sudah baik ada area bermainnya, area terbuka juga ada, ada kursi, ada panggung, toilet juga ada ko terus tempat sama ya ada terus ada tempat nyantai juga ada. tapi menurut saya untuk hari biasa sudah cukup namun jika pengunjung lagi rame pada saat akhir pekan saya kira masih kurang dari segi alat bermain anak-anak dan sumber air masih jauh sehingga menyulitkan dalam penyiraman tanaman dan sumber air" (Informan 2).

RTHP semaki memiliki fasilitas yang kurang lengkap sebab keterbatasan ruang lahan dan berada ditengah pemukiman padat penduduk mengakibatkan sulitnya untuk penambahan fasilitas di RTHP tersebut. fasilitas yang ada di RTHP Semaki adalah area bermain, area terbuka, bangku dan panggung namun tidak memiliki trek lari hanya saja terdapat sirkulasi jalan taman. Fasilitas area bermain meliputi permainan anak-anak seperti prosotan, ayunan dan mangkok puter yang berada di depan RTHP tersebut. Fasilitas bangku terdapat ditengah RTHP namun tidak memiliki atap sehingga tidak dapat untuk meneduh. Panggung balai dusun yang berada disatu lokasi dibelakang RTHP tersebut dapat digunakan untuk kegiatan sosial maupun budaya masyarakat. Informasi tersebut berdasarkan hasil wawancara sebagai berikut.

"Sudah mas kalo saya pribadi sudah mas, ya sudah ada taman, tempat duduk, dan juga ada wifi mas semuanya dapat digunakan bersama-sama oleh masyarakat" (Informan 3).

RTHP Tahunan memiliki fasilitas antara lain area bermain, area terbuka, dan bangku disetiap sudut RTHP, namun tidak terdapat trek lari dan panggung dikarenakan keterbatasan ruang kosong di RTHP tersebut. Fasilitas area bermain yang terdapat di RTHP Tahunan sangat sedikit hanya terdapat ayunan kaki namun kondisinya sudah berkarat tidak layak digunakan. Informasi tersebut berdasarkan hasil wawancara sebagai berikut.

"Belum sih mas disana masih ada alat bermain anak-anak ayunan yang sudah rusak yang seharusnya diperbaiki tapi sampai sekarang belum juga diperbaiki terus toiletnya mas aduuuhhh rusak parah nggak bisa dipake pintunya aj sampe lepas pokoknya parah mas" (Informan 2).

Hal tersebut sejalan dengan penelitian sebelumnya yaitu pembangunan taman akan dilaksanakan 2 tahapan meliputi persiapan dan tahap pelengkapan fasilitas taman tahap satu kegiatan persiapan dan tahap dua meliputi pelengkapan fasilitas seperti pembangunan danau, trek lari, penerangan jalan umum, area parkir, toilet umum, bangunan food court, lampu taman, bangunan cindera mata dan papan informasi(Apriliani, 2015).

Toilet yang ada di RTHP Tahunan kondisinya rusak parah pintu toilet lepas, lampu toilet rusak dan fasilitas air bersih juga tidak tersedia. Dampak dari ketidak tersediaan toilet akan berpengaruh terdahap kesehatan masyarakat sebab apabila tidak ada toilet maka masyarakat dalam membuang air kecil atau besar tidak pada tempatnya sehingga akan 
menimbulkan dampak bagi kesehatan seperti saluran pencernaan, kontaminasi zat racun, hepatitis, dan infeksi cacingan (Tarigan, 2008).

\section{Penilaian Kondisi Fisik}

Kondisi fisik vegetasi yang berada di RTHP Gajahwong Edupark sudah baik mulai dari kesuburan, tertata dan bentuk pemangkasan. Kesuburan tanaman yang di RTHP Gajahwong Edupark terlihat dari kerimbunan tanaman yang sangat lebat dan tidak terdapat tanaman yang layu. RTHP Gajahwong Edupark dalam penataan jenis tanaman sudah cukup baik antara tanaman berbunga dengan tanaman yang yang berukuran besar, pihak DLH baru saja menjalankan program penambahan jenis tanaman sayuran dan buah-buahan di RTHP Gajahwong Edupark. Bentuk pemangkasan di RTHP tersebut sangat rapi karena tidak ada dahan pohon yang mengganggu aktifitas didalam RTHP tersebut. Informasi tersebut berdasarkan hasil wawancara sebagai berikut.

"Menurut saya kondisi fisik RTHP ini sudah cukup baik seperti tanaman subur, tertata rapi dan bentuk tanaman bagus mas, alhamdulillah bersih masyarakat disini kepeduliaannya sangat tinggi. namun alangkah baiknya diberi beberapa hewan seperti kandang burung. kurang tau saya menurut saya sama saja , tetapi dari segi keunggulan disini merupakan RTHP yang terbesar di Umbulharjo dan disini juga kami mengelola kompester guna untuk penambahan pupuk bagi tanaman disini” (Informan 1).

RTHP Tahunan memiliki kondisi vegetasi yang buruk karena terdapat beberapa tanaman yang kering dan layu disebabkan kurangnya penyiraman. Aktivitas anak-anak yang bermain di RTHP tersebut juga salah satu faktor kerusakan vegetasi karena banyak anak-anak yang menginjak tanaman yang ada di RTHP tersebut tanpa ada teguran dari masyarakat sekitar dan kurangnya kesadaran masyarakat dalam menjaga RTHP tersebut. Upaya pihak DLH untuk menghidupkan RTHP tersebut dengan cara melakukan penghijauan namun kondisinya tetap tidak mengalami perubahan yang signifikan. Kondisi ketertatan vegetasi juga masih buruk karena terdapat sisa penebangan pohon yang kondisinya berada di tengah pintu masuk RTHP tersebut sehingga mengganggu aktivitas masyarakat yang berkunjung dan dapat membahayakan anak-anak saat bermain di RTHP tersebut. Bentuk pemangkasan di RTHP Tahunan sudah baik karena tidak ada batang tanaman yang menggangu aktivitas masyarakat di RTHP tersebut. Informasi tersebut berdasarkan hasil wawancara sebagai berikut.

"Kondisi tanaman untuk saat ini masih kurang tertata mas dan di sebelah kanan pojok itukan ada tanaman merambat nah kondiisinya sudah layu kurang disiram dan kebersihannya juga masih kurang mas sole disitu nggak ada tempat sampah emang sih dulu ada tempat sampah dari pemerintah tapi entah kemana ko bisa hilang. Namun tanamannya ini kan baru dihijaukan lagi jadi belum kelihatan hijau ya mas awalnya tampak gersang (masih kurang), dari segi luasnya heheh kayaknya kurang luas ya mas tapi yooo emang gak bisa heheheh" (Informan 1).

RTHP Semaki memiliki kondisi vegetasi yang baik karena masyarakat disana setiap hari menyiram tanaman secara rutin. Kondisi kesuburan di RTHP Semaki terlihat dari tanaman yang hijau, segar dan tidak terdapat tanaman yang layu. Ketertaan vegetasi yang ada di RTHP Semaki sangat baik mulai dari jenis tanaman seperti tanaman bunga dan tanaman pewarna alami untuk membantik. Bentuk pemangkasan yang dilakukan di RTHP Semaki sudah baik karena tidak terdapat tanaman yang menggangu aktivitas di RTHP tersebut. Informasi tersebut berdasarkan hasil wawancara sebagai berikut.

"Yaaaa bagus sih, cukup membantu untuk semisal umpama ada yang punya hajat pas nggak ada tempat misal kan bisa menggunakan area itu. Dari kebersihan sudah bagus mas setiap hari masyarakat bersih-bersih disitu terus kondisi tanamannya juga alhamdulillah subur rapi wes lah enak dilihat." (Informan 1). 
Berdasarkan temuan di lapangan bahwa keunggulan RTHP selain berguna untuk berolahraga dan penghijauan pemukiman terdapat pemberdayaan masyarakat. RTHP Gajahwong Edupark pemberdayaan masyarakat yaitu membuat komposter untuk menambah pupuk tanaman di RTHP Gajahwong Edupark, RTHP Semaki kegiatan pemberdayaan yaitu setiap bulan di RTHP Semaki diadakan kegiatan belajar membatik buat masyarakat yang ingin belajar membatik, RTHP Tahunan tidak terdapat pemberdayaan masyarakat karena antusias masyarakat dilokasi tersebut masih rendah.

\section{Penilaian Aksesibilitas}

Aksesibilitas internal merujuk pada kemudahan pengguna untuk berpindah dari satu tempat ke tempat lainnya yang masih berada di dalam area taman kota dan aksesibilitas eksternal merupakan kemudahan pengguna yang berada di luar kawasan atau letaknya jauh dari lokasi yang akan dituju yaitu moda transportasi baik privat maupun publik dan prasarana transportasi menuju taman. Aksesibilitas didukung oleh mendukung kegiatan olahraga dan non olahraga harus dilengkapi sarana paving block ditaman(Iswara, Astuti and Putri, 2017).

Penilaian aksesbilitas di RTHP Gajahwong Edupark memiliki akses yang cukup baik karena dapat dilewati kendaraan pribadi seperti mobil dan motor namun tidak bisa dilewati oleh kendaraan publik 11 karena tidak berada di jalan utama kota yang dilewati angkutan kota seperti bus hanya saja lokasinya berada di jalan lokal, RTHP Gajahwong Edupark memiliki luas $5000 \mathrm{~m} 2$ serta dilengkapi dengan papan petunjuk arah yang dimana berfungsi sebagai petunjuk bahwa dilokasi tersebut terdapat RTHP. Kontur tanah di RTHP Gajahwong Edupark cukup curam karena berada dipinggir sungai Gajahwong. Sirkulasi jalan dalam RTHP Gajahwong Edupark baik karena kondisi jalan didalam RTHP rata, tidak berlubang, tidak berlumut dan terdapat pengkerasan seperti paving dan bebatuan. Informasi tersebut berdasarkan hasil wawancara sebagai berikut.

"ooooohhhh sangat mudah karena semua kendaraan bisa masuk ketaman ini mas contoh aja mobil mudah, motor sangat mudah, apa lagi sepeda mas. Orang setiap hari libur banyak yang kesini naik mobil mas hahahahah, jalan didalam taman rata tidak berlubang dan tidak berlumut." (Informan 1).

RTHP Tahunan memiliki luas $377 \mathrm{~m} 2$ namun tidak memiliki petunjuk arah karena RTHP tersebut hanya diperuntukan bagi masyarakat sekitar. RTHP Tahunan berada dipinggir jalan besar namun dikelilingi pemukiman padat penduduk sehingga kesulitan dalam menyediakan ruang kosong. Sirkulasi jalan dalam RTHP baik karena terdapat pengkerasan tanah (paving) namun hanya sebangian karena sebagian jalan digunakan sebagai resapan air tanah. Informasi tersebut berdasarkan hasil wawancara sebagai berikut.

"untuk menuju kesini ya mudah nggak sulit-sulit amat sih, soalnya pas dijalan besar juga mas jadi enak langsung dijangkau, untuk jalan didalam taman nggak ada yang lubangnya, dan sebagaian sudah ada batako yang ditanah itu lo" (Informan 1).

Luas RTHP Semaki mencapai luas $860 \mathrm{~m} 2$ memiliki askses yang susah karena hanya dapat dilewati kendaraan roda 2 berada ditengah pemukiman padat penduduk yang memiliki lebar jalan 1,5 untuk memasuki RTHP tersebut harus melihat apakah dari arah berlawanan terdapat pengendara lain sebab tidak bisa berselisihan antar motor. Kondisi jalannya berpaving dengan kondisi kanan dan kiri tembok rumah warga. Sirkulasi dalam taman sangat baik terdapat pengkerasan tanah, rata, tidak berlubang, dan tidak berlumut. Informasi tersebut berdasarkan hasil wawancara sebagai berikut.

"aaadduuuhh mas kendala yang paling besar cuman jalan tok disini sulit kendaraan masuk mas, semisal jika ada acara di taman ini sulit banget kita dalam memasukan semua barangbarang yang dibutuhkan ke dalam taman ini. Alhamdulilah jalan didalam taman sudah dicor mas trs dikasih motif bebatuan juga terlihat lebih indah dan buat terapi kaki juga bisa hahahaha" (Informan 3). 


\section{Partisipasi Masyarakat dalam Pengelolaan RTHP}

Partisipasi masyarakat di ketiga RTHP tersebut berbeda-beda yakni RTHP Gajahwong Edupark partisipasinya sangat baik karena setiap bulan masyarakat melakukan kegiatan gotong royong rutin di RTHP tersebut, kegiatan gotong royong meliputi pembersihan seperti menyapu, memotong dahan yang mengganggu, penyiraman, dan penambahan tanaman jika terdapat kerusakan. Kegiatan gotong royong dikordinir oleh satu orang yang bertanggung jawab sebagai pengelola wilayah, dimana tugas seorang pengelola harus selalu mengajak masyarakat untuk selalu menjaga RTHP tersebut. Pengelola wilayah RTHP yang ditunjuk oleh pihak DLH adalah tokoh masyarakat sekitar guna memberikan efek segan bahwa mereka adalah orang yang terpandang di wilayah tersebut. Informasi tersebut berdasarkan hasil wawancara sebagai berikut.

"Partisipasi masyarakat disini alhamdulillah cukup bagus mereka ikut serta menjaga dan merawat RTHP ini sepengetahuan saya partisipasi masyarakat disini lebih baik dibandingkan RTHP yang lainnya. Partisipasi masyarakat disini ikut membersihkan dan merawat RTHP ini bahkan ada beberapa tanaman yang ada di RTHP ini berasal dari masyarakat tidak hanya dari DLH. Kegiatan dari masyarakat berupa gotong royong setiap bulan minggu pertama seperti menyapu, nyiram tanaman, memangkas pohon dan lain-lain" (Informan 2).

Masyarakat sekitar RTHP Tahunan memiliki partisipasi yang kurang seperti kegiatan gotong royong yang tidak rutin. Kegiatan gotong royong dilakukan hanya ketika ada kegiatan desa saja. Sebagian masyarakat pekerja kantoran sehingga tidak memiliki waktu luang yang banyak untuk merawat RTHP tersebut. Informasi tersebut berdasarkan hasil wawancara sebagai berikut.

"Eemm dari partisipasinya masih kurang karena kan disini banyak yang sibuk dengan pekerjaan masing-masing, rata-rata pekerjaan masyarakat disini banyak bekeraja kantoran" (Informan 1).

RTHP Semaki memiliki partisipasi masyarakat yang sangat baik karena kesadaran masyarakat cukup tinggi masyarakat di RTHP Semaki sangat antusias dalam merawat RTHP tersebut mereka setiap hari tanpa diperintah secara bergiliran selalu membersihkan RTHP tersebut. Selain itu kegiatan lainnya seperti gotong royong selalu rutin dilaksanakan sebulan 2 kali pada hari jumat, namun tanggal pelaksanaannya tergantung kesepakatan pengelola wilayah dan masyarakat. Kegiatan gotong royong meliputi pembersihan dalam skala besar mulai dari penyiraman tanaman, pemangkasan, menyapu dan membersihkan balai dusun. Informasi tersebut berdasarkan hasil wawancara sebagai berikut.

"Bagus....bagus...mereka ikut serta peduli jadi siapa pun yang datang kesini pagi apa sore biasanya ibu-ibu nungguin anak-anak lagi PAUD biasanya menyapu ataupun nyiram bahkan sampe ngepel lantai ini mas, kita gantian fleksibel aj sih mas. Itu rutin mas terutama sore mas karena sore itu tempat anak-anak bermain. Kalo jadwal tetap gotong royong itu sebulan sekali kami bersihbersih ngubeng (mutar) wilayah itu kadang ngambil minggu kedua atau ketiga hari jumat biasanya jumat bersih kita sih janjian aj mas antara warga gitu" (Informan 3).

\section{SIMPULAN DAN SARAN}

\section{Simpulan}

Pengelolaan yang dilakukan oleh DLH Kota Yogyakarta ketiga RTHP tersebut berbeda-beda tergantung fungsi RTHPnya. Vegetasi yang ada disana bervariasi seperti tanaman berkayu keras dan tidak berkayu. Perawatan yang dilakukan pihak DLH semuanya sudak baik, mulai dari pemupukan, pengiraman, pemangkasan dan pengendalian hama yang rutin dilakukan oleh pihak DLH. Fasilitas yang ada di di RTHP Gajahwong dan Semaki 
cukup lengkap dan masyarakatnya menjaga dan merawat fasilitas dengan baik sedangkan RTHP Tahunan kurang terawat. Kondisi fisik pada RTHP Gajahwong Edupark dan Semaki memiliki kondisi fisik seperti vegetasi dan kebersihan semuanya baik sedangkan RTHP Tahunan kurang terawat. Akses pada RTHP Gajahwong Edupark dan Tahunan memiliki akses eksternal yang baik dapat dilewati kendaraan pribadi seperti mobil dan moton namun tidak dapat dilewati oleh kendaraan umum. RTHP Semaki memiliki 14 akses yang sulit sebab terdapat ditengah pemukiman padat penduduk.

\section{Saran}

1. Bagi Dinas Lingkungan Hidup Kota Yogyakarta

a. Diharapkan adanya sosialisasi masyarakat bagimana fungsi dan manfaat RTHP bagi kawasan pemukiman, sehingga tidak terjadi perbedaan presepsi antara pihak DLH Kota Yogyakarta dengan masyarakat sekitar.

b. Diharapkan lebih efektif lagi dari segi frekuensi dan jumlah personil dalam perawatan ke RTHP di seluruh Kota Yogyakarta.

2. Masyarakat sebagai pengguna seharusnya lebih peduli dalam menjaga dan merawat RTHP di wilayahnya, lebih ditingkatkan partisipasi masyarakatnya karena jangan berpatokan dengan perawatan dari DLH yang tidak rutin setiap hari, oleh karena itu peran masyarakat menciptakan RTHP yang aman dan nyaman dipangaruhi peran masyarakat sangat besar yang dalam menjaganya.

\section{DAFTAR PUSTAKA}

Apriliani, V. (2015) Desain Pengelolaan Ruang Terbuka Hijau Di Kawasan Sumber Komplek Perkantoran Kabupaten Cirebon. Universitas Diponegoro, Semarang.

Budiman, A., Sulistyantara, B. and Zain, A. F. (2014) 'Deteksi Perubahan Ruang Terbuka Hijau Pada 5 Kota Besar Di Pulau Jawa’, Jurnal Lanskap Indonesia, 6(1), pp. 7-15.

DLH Kota Yogyakarta (2018) Data Luas Ruang Terbuka Hijau Publik Tahun 2011-2018 Kota Yogyakarta. Yogyakarta.

Harahap, F. R. (2013) 'Dampak Urbanisasi Bagi Perkembangan Kota di Indonesia', Jurnal Society, 1(1), pp. 35-45.

Iswara, R., Astuti, W. and Putri, R. A. (2017) 'Kesesuaian Fungsi Taman Kota Dalam Mendukung Konsep Kota Layak Huni Di Surakarta', Jurnal Arsitektura, 15(1), pp. 115123.

Kementerian Pekerjaan Umum (2008) Peraturan Menteri Pekerjaan Umum Nomor: 05/PRT/M/2008 Tentang Pedoman Penyediaan dan Pemanfaatan Ruang Terbuka Hijau di Perkotaan. Jakarta.

Kementerian Pekerjaan Umum (2012) Peraturan Menteri Pekerjaan Umum No. 05/PRT/M/2012 Tentang Pedoman Penanaman Pohon Pada Sistem Jaringan Jalan.

Nugroho, M. L. E. (2015) Problematika Penyediaan Ruang Terbuka Hijau di Kota Semarang. Universitas Diponegoro Semarang.

Perwali (2016) Peraturan Walikota Yogyakarta No.05 Tentang Ruang Terbuka Hijau. Yogyakarta.

Rushayati, S, B. et al. (2011) 'Pengembangan Ruang Terbuka Hijau Berdasarkan Distribusi Suhu Permukaan di kabupaten Bandung', Jurnal Forum Geografi, 25(1), pp. 17-26.

Siregar, M, A, H. (2014) Fungsi Ruang Terbuka Hijau Dalam Tata Ruang Kota Ditinjau Dari Perspektif Hukum Adinistrasi Negara. Universitas Sumatera Utara.

Tarigan (2008) Membaca Sebagai Suatu Ketreampilan Berbahasa. Bandung: Angkasa. 